\title{
Analysis of Consumer Demand and Preference for Rabbit Meat in Benin
}

\author{
Jean Adanguidi ${ }^{1}$ \\ ${ }^{1}$ Faculty of Economic and Management, University of Abomey-Calavi, Benin \\ Correspondence: Jean Adanguidi, Faculty of Economic and Management, University of Abomey-Calavi, 03 BP \\ 0984, Benin. E-mail: a60j60@gmail.com
}

Received: November 22, 2019 Accepted: January 2, 2020 Online Published: February 7, 2020

doi:10.5539/ijms.v12n1p14 URL: https://doi.org/10.5539/ijms.v12n1p14

\begin{abstract}
The demand for rabbit meat exists and would only be satisfied at $50 \%$ and the holiday periods often have quite high demands. This demand is growing rapidly as it is increasingly valued by Beninese with modest incomes in search of dietary diversification and limiting cholesterol average. Rabbits are sold at a relatively high price in the Ouémé/Plateau region compared to other regions of the country, due to the higher demand there. Rabbits produced in South Benin are relatively more competitive compared to imported rabbit meat. Consumers of rabbit meat are mainly active civil servants (50\% of cases) and low-income individuals. These consumers believe that locally produced rabbit is of very good quality and tastes very good.
\end{abstract}

Keywords: rabbit demand, consumer preference, Kendall test, Benin

\section{Introduction}

Rabbit breeding and trade in Benin really began in the 1980s with the support of various partners, including the FAO, the National Institute of Agronomic Research of France, Louvain Développement, the Millenium Challenge Account, etc. Its livestock is well adapted to the landlessness constraints faced by many rural populations, especially in the southern part of the country (Djago, 1998). The meat yield of rabbits is also high: $1.30 \mathrm{~kg}$ of carcass in 4 months under Benin's climatic conditions. It has already become part of the dietary habits of the country's populations (Goudjo, 2010) because of its nutritional characteristics: rabbit meat is rich in protein, essential amino acids, polyunsaturated fatty acids (linoleic acid) and iron $(5.3 \mathrm{mg} / \mathrm{kg}$ fresh substance). However, it is low in fat, sodium and cholesterol (Lücker et al., 1998; Djago et al., 2010; Zotte \& Szendrö, 2011; Nakyinsige et al., 2015). It is recommended for use in weight reduction diets or diets for the elderly or people with heart disease (Beal et al., 2004).

Most of the research conducted on rabbits in Benin to date has often focused on carcass production and yield (Djago, 1998; Goudjo, 2010). To our knowledge, no study has yet addressed the crucial issue of the demand and consumption of rabbit meat in Benin. However, such a study is essential to better understand the driving forces that stimulate production, and therefore lead rabbit farmers to adopt the best practice developed by researchers. In the same way, the knowledge of consumers' perceptions on specific product is considered as a critical success factor in today's competitive market (Montero-Vicente et al., 2018; Groot \& Albisu, 2015; McEachern \& Schröder, 2004).

The objective of this study is to fill this gap by analyzing the demand and consumption of rabbit meat in Benin.

\section{Research Method}

\subsection{Data Used}

The study covered all rabbit production areas in Benin, including the departments of Alibori, Atlantique, Borgou, Collines, Littoral, Couffo, Mono, Ouémé, Plateau and Zou. The investigation was conducted in two phases:

- An initial exploratory phase based on semi-structured interviews with resource persons including extension agents, researchers and some producer organizations. The aim here is to understand the consumption and the demand for rabbit meat as well as the identification of where the rabbit and its meat are sold, etc. Twenty-one points of sale were selected at the end of this phase (Table 1).

- A second quantitative phase carried out on a sample of consumers selected (survey for the quantitative phase) 
by the so-called accidental sampling method. The approach consists in positioning an investigator with a trader, in restaurant or butcher specialized in rabbit meat, at a time chosen by chance between 9:00 am and 6:00 pm. On the spot, he will collect information from two to three rabbit consumers who came just after him. The data collected relate to the consumer's profile (sex, age, education level, residence, main activity, average monthly income level, etc.), rabbit consumption (forms, frequencies, restaurant, etc.) and consumer preference factors for rabbit meat.

Table 1. Distribution of the sample according to regions and categories of actors

\begin{tabular}{lllllll}
\hline Category of actors & REGION & & & & \multicolumn{2}{c}{ Together } \\
\cline { 2 - 5 } & $\begin{array}{l}\text { Atlantique } \\
\text { /Littoral }\end{array}$ & $\begin{array}{l}\text { Borgou } \\
\text { /Alibori }\end{array}$ & $\begin{array}{l}\text { Mono/ } \\
\text { Couffo }\end{array}$ & $\begin{array}{l}\text { Ouémé/ } \\
\text { Plateau }\end{array}$ & $\begin{array}{l}\text { Zou/ } \\
\text { Collines }\end{array}$ \\
\hline Consumer & 10 & 5 & 5 & 10 & 2 & $\mathbf{3 2}$ \\
Restaurant or Butcher specialized in rabbit meat & 5 & 3 & 4 & 6 & 4 & $\mathbf{2 2}$ \\
Total & $\mathbf{1 5}$ & $\mathbf{8}$ & $\mathbf{9}$ & $\mathbf{1 6}$ & $\mathbf{6}$ & $\mathbf{5 4}$ \\
\hline
\end{tabular}

\subsection{Data Analysis}

First, we used descriptive statistical tools (mean, standard deviation, frequencies, etc.) to analyze the collected data. Then, the reasons underlying the consumption of rabbit meat, the determinants of rabbit meat purchase and the main types of meat consumed (expenditures, preferences) were classified by the consumers surveyed. Then, we performed a concordance analysis of the reasons and determinants using the Kendall test, which is as follows:

By designating $\mathrm{n}$ as the number of experts who have made rankings, the Spearman concordance coefficient is calculated for each pair of experts surveyed. We will get then $n(n-1) / 2$ Spearman correlation coefficients.

If $\bar{r}_{S}$ is the simple arithmetic mean of the $\mathrm{n}(\mathrm{n}-1) / 2$ Spearman correlation coefficients, the Kendall correlation coefficient (W) will be defined as follows (Dagnelie, 1998):

$$
W=\left[1+(n-1) \bar{r}_{S}\right] / n
$$

$\mathrm{W}$ varies between 0 and 1 . Values close to 0 reflect a significant discrepancy between rankings; and values close to 1 reflect a high degree of agreement between rankings.

\section{Results and Discussion}

\subsection{Socioeconomic Profile of Consumers}

Men dominate the rabbit meat consumers surveyed ( $81 \%$ of cases). Women are also among consumers in the departments of Alibori, Atlantique, Borgou, Collines, Littoral, Couffo, Mono and Zou. The average age of consumers is 39 years. The educational level of rabbit meat consumers is on average 12 years old, i.e., the level of the Secondary School class (Table 2). The lowest level, about 7 years, was observed in Mono and Couffo departments; and the highest level, about 18 years, was obtained in Collines and Zou departments.

In $91 \%$ of cases, rabbit meat consumers are married. They are heads of households ( $84 \%$ of cases) and live mainly in large cities such as Cotonou, Abomey-Calavi, Porto-Novo, Parakou, Djougou, etc.

They are active civil servants (50\% of cases) and traders (19\% of cases). There are also a few retired public servants and farmers. This is proof that not everyone has access to rabbit meat: $97 \%$ of consumers have a monthly income of more than CFAF 50,000. Better still, 59\% of consumers have a monthly income between 50,000 and 100,000 CFA francs and 22\% have a monthly income between 100,000 and 200,000 CFA francs.

In short, consumers of rabbit meat are generally active civil servants with relatively moderate incomes. As point out by Delport et al. (2017) in South Africa, since meat is a normal or luxury good for the majority of the people, a rise in real disposable income will lead to an increase in the consumption of meat.

These results confirm those of previous studies in other geographical contexts that have shown that there is a relationship between rabbit meat consumption and age, gender and occupational status (McLean-Meyinsse, 2000; Beal et al., 2004; González-Redondo, 2010). 
Table 2. Some characteristics of rabbit meat consumers

\begin{tabular}{|c|c|c|c|c|c|c|}
\hline & \multicolumn{5}{|c|}{ Departments } & \multirow[t]{2}{*}{ Together } \\
\hline & $\begin{array}{l}\text { Ouémé/ } \\
\text { Plateau }\end{array}$ & $\begin{array}{l}\text { Atlantique } \\
\text { /Littoral } \\
\end{array}$ & $\begin{array}{l}\text { Zou/ } \\
\text { Collines }\end{array}$ & $\begin{array}{l}\text { Borgou } \\
\text { /Alibori }\end{array}$ & $\begin{array}{l}\text { Mono/ } \\
\text { Couffo }\end{array}$ & \\
\hline \multicolumn{7}{|l|}{ Consumer gender $(\%)$} \\
\hline Man & 100.0 & 80.0 & 100.0 & 60.0 & 60.0 & 81.0 \\
\hline Woman & 0.0 & 20.0 & 0.0 & 40.0 & 40.0 & 19.0 \\
\hline \multirow[t]{2}{*}{ Age of the consumer (year) } & 41.6 & 38.3 & 40.0 & 34.6 & 36.6 & 38.6 \\
\hline & $(4.6)$ & $(13.0)$ & $(7.1)$ & $(6.7)$ & $(9.1$ & $(8.9)$ \\
\hline \multirow[t]{2}{*}{ Consumer education level (year) } & 10.5 & 13.9 & 17.5 & 14.4 & 7.2 & 12.1 \\
\hline & $(5.5)$ & $(4.8)$ & $(0.7)$ & $(3.9)$ & $(5.7)$ & $(5.5)$ \\
\hline \multicolumn{7}{|l|}{ Consumer's marital status } \\
\hline Married & 100.0 & 90.0 & 100.0 & 80.0 & 80.0 & 90.6 \\
\hline Single & 0.0 & 10.0 & 0.0 & 20.0 & 20.0 & 9.4 \\
\hline \multicolumn{7}{|l|}{ Consumer's main activity } \\
\hline Farmer & 0.0 & 0.0 & 0.0 & 0.0 & 20.0 & 3.1 \\
\hline Trade & 10.0 & 20.0 & 0.0 & 20.0 & 40.0 & 18.8 \\
\hline Public/private/public sector & 70.0 & 60.0 & 100.0 & 60.0 & 20.0 & 59.4 \\
\hline \multicolumn{7}{|l|}{ official } \\
\hline Retired staff member & 0.0 & 10.0 & 0.0 & 0.0 & 0.0 & 3.1 \\
\hline Others (craftsman, tourist, etc.) & 20.0 & 10.0 & 0.0 & 20.0 & 20.0 & 15.6 \\
\hline \multicolumn{7}{|l|}{ Average monthly consumer income level (FCFA) } \\
\hline$\leq 50000$ & 0.0 & 0.0 & 0.0 & 20.0 & 0.0 & 3.1 \\
\hline$[50000,100000]$ & 70.0 & 40.0 & 0.0 & 60.0 & 100.0 & 59.4 \\
\hline$[100000,200000]$ & 30.0 & 20.0 & 50.0 & 20.0 & 0.0 & 21.9 \\
\hline$[200000,400000]$ & 0.0 & 30.0 & 50.0 & 0.0 & 0.0 & 12.5 \\
\hline$>400000$ & 0.0 & 10.0 & 0.0 & 0.0 & 0.0 & 3.1 \\
\hline \multicolumn{7}{|l|}{ Position of the consumer in his household } \\
\hline Head of household & 100.0 & 80.0 & 100.0 & 60.0 & 80.0 & 84.4 \\
\hline Spouse/Wife & 0.0 & 10.0 & 0.0 & 20.0 & 20.0 & 9.4 \\
\hline Child of the head of household & 0.0 & 10.0 & 0.0 & 20.0 & 0.0 & 6.2 \\
\hline \multicolumn{7}{|l|}{ Place of residence of the consumer } \\
\hline Cotonou & 40.0 & 30.0 & 50.0 & 0.0 & 0.0 & 25.0 \\
\hline Porto-Novo & 60.0 & 0.0 & 0.0 & 0.0 & 0.0 & 18.8 \\
\hline Other (Parakou, Lokossa, Abomey-Calavi, etc.) & 0.0 & 70.0 & 50.0 & 100.0 & 100.0 & 56.2 \\
\hline
\end{tabular}

\subsection{Place of Rabbit Meat}

We analyzed the place of rabbit meat among the meat products consumed by the respondents. The data collected show that almost all respondents consume traditional chicken also called bicycle chicken ( $97 \%$ of cases). About $91 \%$ of respondents also eat fish. Next come goats ( $69 \%$ of cases), improved/imported chicken $(61 \%$ of cases) and beef meat ( $56 \%$ of cases) (see Figure 1).

The respondents were asked to classify the meat products consumed on the basis of expenditure and preferences.

Analysis of the concordance of the rankings made by the respondents (see Table 3) shows that fish is in first place in terms of expenditure, while rabbits are in fourth place.

In terms of preference, rabbits come in second place after local chickens. Although rabbit is more popular than fish and goats, consumers spend less on it. This can be explained by the price of rabbit, which is relatively higher than that of other meat products. As a result, rabbit meat consumption is somewhat modest in the eating habits of the average Beninese.

The relatively high price of farmed rabbits makes them less competitive compared to chicken (Mailu et al., 2012). This result is also confirmed by Petrescu and Petrescu-Mag (2018) in a study carried out in Romanian where they found that rabbit meat is perceived as low cholesterol and lean, tastier and healthier than other meats, but is more expensive, that its consumption is low, being 2.2 times lower than chicken and 1.8 times lower than pork, and that $29.6 \%$ of people surveyed have never eaten rabbit meat.

This result is however not consistent with the result of Montero-Vicente et al. (2018) who analyzed the commercial value of rabbit meat based on positioning of the different types of fresh meat. They found in their study that commercially, rabbit meat did not compete with any other fresh meat. 


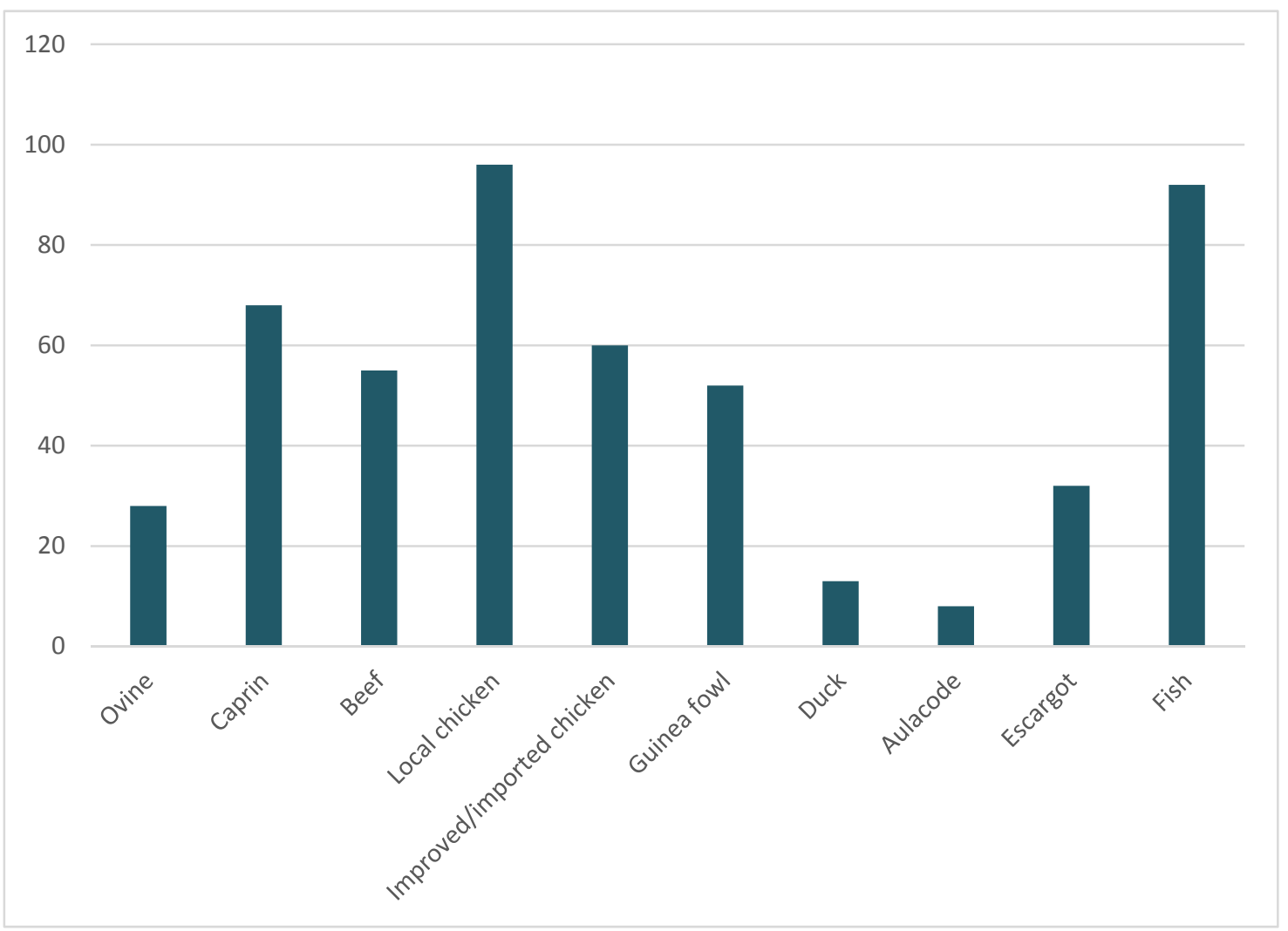

Figure 1. Types of meat consumed outside the rabbit

Table 3. Classification of meat consumed based on expenditure and preferences

\begin{tabular}{lllll}
\hline Products & Expenditure & \multicolumn{3}{l}{ Preferences } \\
\cline { 2 - 5 } & Average rank & Order & Average rank & Order \\
\hline Sheep & 7.38 & 8 & 8.06 & 9 \\
Goat & 4.23 & 2 & 5.17 & 4 \\
Beef & 5.80 & 6 & 6.58 & 6 \\
Local chicken & 4.25 & 3 & 2.50 & 1 \\
Improved/imported chicken & 5.66 & 5 & 6.45 & 5 \\
Rabbit & 4.38 & 4 & 2.78 & 2 \\
Guinea fowl & 6.55 & 7 & 6.62 & 7 \\
Duck & 7.94 & 10 & 8.53 & 10 \\
Thryonomys swinderianus & 8.34 & 11 & 8.56 & 11 \\
Snail & 7.73 & 9 & 7.22 & 8 \\
Fish & 3.75 & 1 & 3.52 & 3 \\
\hline Kendall's test & & & & \\
$\quad N$ & & 32 & & 32 \\
Wof Kendall & 0.366 & & 0.515 \\
Khi-deux & 116.988 & & 164.7 \\
Dl & & 10 & & 10 \\
Probability & & 0.000 & & 0.000 \\
\hline
\end{tabular}

\subsection{Rabbit Consumption Patterns}

The consumers surveyed obtain their supplies from live rabbits ( $50 \%$ of respondents), rabbit carcasses ( $29 \%$ of respondents) or processed rabbits in various forms (see Table 4). About $73 \%$ of respondents buy braised rabbit meat and $52 \%$ buy grilled or fried rabbit meat, mainly with peanut oil. Some respondents buy rabbit prepared in peanut sauce or tomato sauce ( $43 \%$ of cases). Rabbit meat is sometimes purchased as skewers ( $59 \%$ of cases).

The data collected suggest a regional specialization in consumption patterns. So, for example: 
- Respondents from the departments of Zou and the hills have a preference for live rabbit, carcass and braised, grilled or sautéed meat.

- Respondents in the departments of Ouémé and Plateau have a preference for braised rabbit ( $90 \%$ of cases) and rabbit skewers $(80 \%$ of cases). This is understandable since these two departments have a long tradition in the consumption of pork skewers.

- Respondents in the Atlantic and Littoral departments obtain supplies of live rabbit (70\% of cases) and braised rabbit/rabbit skewers (70\% of cases).

Table 4. Distribution of respondents according to the condition of the rabbit purchased

\begin{tabular}{lllllll}
\hline Rabbit condition & \multicolumn{2}{l}{ Departments } & \multicolumn{2}{c}{ Together } \\
\cline { 2 - 5 } & $\begin{array}{l}\text { Ouémé/ } \\
\text { Plateau }\end{array}$ & $\begin{array}{l}\text { Atlantique } \\
\text { /Littoral }\end{array}$ & $\begin{array}{l}\text { Zou/ } \\
\text { Collines }\end{array}$ & $\begin{array}{l}\text { Borgou } \\
\text { /Alibori }\end{array}$ & $\begin{array}{l}\text { Mono/ } \\
\text { Couffo }\end{array}$ & \\
\hline Live rabbit (live) & 20.0 & 70.0 & 100.0 & 20.0 & 80.0 & 50.0 \\
Carcass & 10.0 & 56.0 & 50.0 & 40.0 & 0.0 & 29.0 \\
Grilled rabbit & 60.0 & 44.0 & 100.0 & 60.0 & 20.0 & 52.0 \\
Braised rabbit & 90.0 & 62.0 & 100.0 & 80.0 & 40.0 & 73.0 \\
Jumpy rabbit & 40.0 & 13.0 & 100.0 & 60.0 & 60.0 & 43.0 \\
Rabbit skewer & 80.0 & 62.0 & 0.0 & 40.0 & 33.0 & 59.0 \\
\hline
\end{tabular}

\subsection{Demand for Rabbit Products}

The average frequency of purchase of rabbit products is three times a month. The average expenditure is CFAF 3,839 (see Table 5). The frequency of rabbit purchases in the departments of Ouémé and Plateau is relatively higher than in the other departments (on average four times per month). The departments of Mono and Couffo are in second place with an average of 3.6 times per month.

This frequency of consumption remains low and confirms the results obtained by Mailu et al. (2012) in a study conducted in Kenya. These authors found that the frequency of rabbit meat consumption was very low, even among rabbit farmers $(46 \%$ of them did so at most once every 12 months, compared to 73 percent among non-rabbit farmers).

According to the consumers surveyed, several factors limit rabbit consumption (see Table 6):

- The first factor according to $56 \%$ of the respondents is the purchase price, which seems to be relatively high compared to that of chicken or small ruminant meat.

- The second factor according to $38 \%$ of the respondents is the low availability of rabbit meat during certain periods of the year. This is because some producers run out of stock during the holiday season (Easter, end of year, etc.). This is proof that the demand for rabbit meat is even higher than the supply and that there is still a market for this meat.

- Other limiting factors mentioned by respondents are distance from points of sale, storage difficulties and product quality.

The results of the study are in line with those found by other authors:

- Abdul-Rahman et al. (2019) in their research the Tamale metropolis in the Northern region of Ghana, found that price instability was ranked as the first constraint to guinea fowl consumption. About $93.7 \%$ of the consumers indicated that there are seasonal fluctuations in the price of guinea fowl leading to the use of products that are substitutes for guinea fowl.

- Ellies-Oury et al. (2019) in a study conducted in France, found that the decline in meat consumption may be explained by the high price of beef, and concerns about health, environment, eating quality and animal welfare.

- Udomkun et al. (2018) in their study in Democratic Republic of Congo found that 53\% of the respondents were dissatisfied with meat products in the market due to their high price, low quantity, unhealthiness, and harmful effects.

- Bodnár (2009) in a study carried out in Hungary showed that $46 \%$ of respondents found rabbit meat too expensive in shops and only buy it once or twice a year.

Other studies, however, have shown that price is not the determining factor in consumer purchasing behavior: 
- Uys and Bisschoff (2016) in their study in South Africa identified eight factors which influenced the buying behavior of consumers when they are purchasing beef products: quality of the meat, buying preference, farming practices, intention to buy, health, convenience, packaging \& presentation and future purchase. The meat price was not mentioned here.

- Mottin et al. (2019) in a study on the cattle meat consumption in Brasilia found that the presentation of the product is regarded as the most important attribute at the time of purchase.

Table 5. Frequency of purchase (per month) and monthly expenses for rabbit (FCFA)

\begin{tabular}{lllllll}
\hline & \multicolumn{2}{l}{ Departments } & & & Ensemble \\
\cline { 2 - 6 } & Ouémé & Atlantique/Littoral & Zou/Collines & Borgou /Alibori & Mono/ Couffo & \\
\hline Frequency & $4.2(2.7)$ & $1.1(0.5)$ & $3.0(0.0)$ & $2.8(1.8)$ & $3.6(2.6)$ & $2.9(2.3)$ \\
Expenses & 3300.0 & 3900.0 & 5000.0 & 4000.0 & 4200.0 & 3838.7 \\
& $(888.2)$ & $(1329.2)$ & $(3535.5)$ & $(707.1)$ & $(2841.7)$ & $(1588.4)$ \\
\hline
\end{tabular}

Table 6. Factors limiting rabbit consumption

\begin{tabular}{|c|c|c|c|c|c|c|}
\hline & \multicolumn{5}{|c|}{ Departments } & \multirow[t]{2}{*}{ Ensemble } \\
\hline & $\begin{array}{l}\text { Ouémé/ } \\
\text { Plateau }\end{array}$ & $\begin{array}{l}\text { Atlantique } \\
\text { /Littoral } \\
\end{array}$ & $\begin{array}{l}\text { Zou/ } \\
\text { Collines }\end{array}$ & $\begin{array}{l}\text { Borgou } \\
\text { /Alibori } \\
\end{array}$ & $\begin{array}{l}\text { Mono/ } \\
\text { Couffo } \\
\end{array}$ & \\
\hline Low availability & 100.0 & 10.0 & 0.0 & 20.0 & 0.0 & 38.0 \\
\hline Low purchasing power & 40.0 & 30.0 & 50.0 & 0.0 & 20.0 & 28.0 \\
\hline High purchase price & 80.0 & 60.0 & 50.0 & 40.0 & 20.0 & 56.0 \\
\hline Product quality & 0.0 & 33.0 & 0.0 & 20.0 & 0.0 & 13.0 \\
\hline Storage problems & 0.0 & 22.0 & 0.0 & 0.0 & 20.0 & 10.0 \\
\hline Distance from the place of purchase & 30.0 & 40.0 & 0.0 & 0.0 & 20.0 & 26.0 \\
\hline
\end{tabular}

\subsection{Analysis of Factors Influencing Consumer Preference}

According to our investigations, several factors explain consumers' preference for rabbit meat (see Table 7):

- The type of meat: During the purchase, consumers prefer either the farmed rabbit (more preferred) or the imported rabbit;

- The taste;

- The amount of grease;

- The selling price.

These results are similar to those obtained by De Carlo et al. (1999) in an Italian rabbit meat market study where they showed that consumers are attracted by the following criteria in descending order: quality, appearance, carcass weight and price/quality ratio. However, according to Zotte (2002), these criteria only apply to traditional consumers ( $76 \%$ of respondents).

The attraction of rabbit meat to the majority of consumers is due to its taste ( $97 \%$ of respondents). About $88 \%$ of consumers said that rabbit meat is good for their health (see Table 8). The ranking of preference criteria indicates (see Table 9) that pleasure and good taste are the main reasons why respondents consume rabbits. Health comes in second place while the non-seeking of rabbit meat comes in last place. Consumers believe that rabbit is a white meat, cholesterol-free, very tender and good for diabetics and all those who have an aversion to red meat.

These results confirm those found by some authors:

- Szendrö (2016) found in his study on Consumer perceptions of rabbit meat in Hungary that respondents basically found rabbit meat healthy;

- Zotte and Szendrö (2011) found that rabbit meat contains the lowest cholesterol levels (47.0 and 61.2 milligrams/100 grams) of all popular meats.

- Cavani et al. (2009), Hernández et al. (2006) and Nakyinsige et al. (2015) have shown that rabbit meat meets the current need, i.e., consumer demand, for low-fat meat with a high level of unsaturated fatty acids and low cholesterol and sodium levels.

- Lukefahr et al. (1989) and Zotte (2002) pointed out that rabbit meat is characterized by a low-fat content (on average 6.8 grams/100 grams fresh meat) and a low-calorie content (on average $618 \mathrm{~kJ} / 100$ grams fresh 
meat) compared to red meat. Rabbit meat, according to these authors, contains the lowest cholesterol levels among the most popular meats (on average $53 \mathrm{mg} / 100 \mathrm{~g}$ of fresh meat). And it is precisely these qualities that led McLean-Meyinsse (2000) to say that any promotional effort to increase rabbit meat consumption must focus on the nutritional attributes of the meat rather than its price.

Table 7. Prioritization of preferred factors when purchasing rabbit meat: result of Kendall's concordance test

\begin{tabular}{lllll}
\hline Criteria & Average rank & Order & Statistical test & \\
\hline Taste & 3.70 & 2 & $\mathrm{~N}$ & 32 \\
Smell of meat & 5.69 & 7 & W de Kendall & 0.259 \\
Texture & 4.91 & 5 & Khi-deux & 66.356 \\
Color & 5.45 & 6 & ddl & 8 \\
Fat content & 4.42 & 3 & Probability & 0 \\
Prices & 4.86 & 4 & & \\
Type & 2.70 & 1 & & \\
Geographical origin & 7.00 & 9 & & \\
Weight & 6.27 & 8 & & \\
\hline
\end{tabular}

Note. $\mathrm{N}=$ Number of observations, $\mathrm{ddl}=$ Degree of freedom.

Table 8. Motivations for eating rabbit meat

\begin{tabular}{lllllll}
\hline Reasons & Department & & & & Together \\
\cline { 2 - 5 } & $\begin{array}{l}\text { Ouémé/ } \\
\text { Plateau }\end{array}$ & $\begin{array}{l}\text { Atlantique } \\
\text { /Littoral }\end{array}$ & $\begin{array}{l}\text { Zou/ } \\
\text { Collines }\end{array}$ & $\begin{array}{l}\text { Borgou } \\
\text { /Alibori }\end{array}$ & $\begin{array}{l}\text { Mono/ } \\
\text { Couffo }\end{array}$ & \\
\hline Cheap & 90.0 & 0.0 & 50.0 & 0.0 & 0.0 & 31.0 \\
Accessible point of sale & 80.0 & 40.0 & 50.0 & 20.0 & 80.0 & 56.0 \\
Good tastes & 100.0 & 90.0 & 100.0 & 100.0 & 100.0 & 97.0 \\
Good for health & 100.0 & 80.0 & 50.0 & 80.0 & 100.0 & 88.0 \\
Eating pattern & 90.0 & 20.0 & 0.0 & 100.0 & 0.0 & 50.0 \\
\hline
\end{tabular}

Table 9. Ranking of motivations underlying the consumption of rabbit meat

\begin{tabular}{lllll}
\hline Reasons & Average rank & Order & Kendall's test & \\
\hline Cheap & 4.15 & 5 & $\mathrm{~N}$ & 31 \\
Accessible point of sale & 3.81 & 4 & W de Kendall & 0.61 \\
Good tastes & 1.58 & 1 & Khi-deux & 75.63 \\
Good for health & 1.87 & 2 & $\mathrm{~d} l$ & 4 \\
Eating pattern & 3.60 & 3 & Probability & 0.00 \\
\hline
\end{tabular}

\section{Concluding Remarks}

The demand for rabbit meat exists and would only be satisfied at $50 \%$ and the holiday periods often have quite high demands. Consumers of rabbit meat are mainly active civil servants and traders. In $91 \%$ of cases, rabbit meat consumers are married. They are heads of households ( $84 \%$ of cases) and live mainly in large cities such as Cotonou, Abomey-Calavi, Porto-Novo, Parakou, Djougou, etc.

The local rabbit would be of very good quality and has a very good taste. The relatively high price of rabbit meat means that its consumption is somewhat modest compared to the eating habits of Beninese, but the demand for this meat is increasing as it is increasingly valued by Beninese with modest incomes in search of food diversification and limiting cholesterol consumption.

As suggested by Petrescu and Petrescu-Mag (2018) and Buitrago-Vera et al. (2016), the results of this study can help marketers mainly focusing on how to increase rabbit consumption, to better design a commercial strategy adapted to market constraints.

\section{References}

Abdul-Rahman, I. I., Angsongna, C. B., \& Baba, H. (2019). Guinea fowl (Numida Meliagris) value chain: preferences and constraints of consumers. Afr. J. Food Agric. Nutr. Dev., 19(2), 14393-14414. https://doi.org/10.18697/ajfand.85.17335 
Beal, M. N., McLean-Meyinsse, P. E., \& Atkinson, C. (2004). An Analysis of Household Consumption of Rabbit Meat in the Southern United States. Journal of Food Distribution Research, 35(1), 24-29.

Bodnár, K. (2009). Rabbit production and consumption in Hungary. Lucrări Ştiinţifice, Seria Agronomie, 52, 69-72.

Buitrago-Vera, J., Escribá-Pérez, C., Baviera-Puig, A., \& Montero-Vicente, L. (2016). Consumer segmentation based on food-related lifestyles and analysis of rabbit meat consumption. World Rabbit Sci., 24, 169-182. https://doi.org/10.4995/wrs.2016.4229

Carlos de, B., Javier, G., \& Rosa, C. (1999). Role of fibre in rabbit diets. A review. Annales de Zootechnie, 48(1), 3-13. https://doi.org/10.1051/animres:19990101

Delport, M., Louw, M., Davids, T., Vermeulen, H., \& Meyer, F. (2017). Evaluating the demand for meat in South Africa: an econometric estimation of short-term demand elasticities. Agrekon, 56(1), 13-27. https://doi.org/10.1080/03031853.2017.1286249

Djago, A. Y. (1998). Zootechnie et gestion d'une exploitation cunicole. Rapport FAO Cotonou.

Djago, A. Y., Kpodékon, M., \& Lebas, F. (2010). Guide pratique d'élevage de lapin sous les tropiques (2ème édition, p. 119). CECURI (Centre Cunicole de Recherche et d'Information). Abomey-Calavi.

Ellies-Oury, M.-P., Lee, A., Jacob, H., \& Hocquette, J.-F. (2019). Meat consumption-what French consumers feel about the quality of beef? Italian Journal of Animal Science, 18(1), 646-656. https://doi.org/10.1080/1828051X.2018.1551072

González-Redondo, P., Mena, Y., \& Fernández-Cabanás, V. M. (2010). Factors Affecting Rabbit Meat Consumption among Spanish University Students. Ecology of Food and Nutrition, 49(4), 298-315. https://doi.org/10.1080/03670244.2010.491053

Goudjo, E. A. (2010). Évaluation des performances de reproduction des lapines en sélection et des femelles croisées avec des mâles de souche INRA 1777 au CECURI (Centre Cunicole de Recherche et d'Information) Bénin. Mémoire pour Master Professionnel. Université d'Abomey-Calavi.

Groot, E., \& Albisu, L. M. (2015). A bottom-up model to describe consumers' preferences towards late season peaches. Span. J. Agric. Res., 13(4), e0110. https://doi.org/10.5424/ sjar/2015134-7605.

Lamanna, M. L., Cossu, M. E., Picallo, A., Gambetti, P., Cumini, M. L., \& Grigol, I. (2014). Sensory meat quality: influence of diet supplemented with oil and antioxidants in fattening rabbits (pp. 516-521). V Congreso Americano de Cunicultura, México.

Lücker, E., Failing, K., Lange, K., Walker, G., \& Bülte, M. (1998). Content and Distribution of Iron in Rabbit Meat. A Model Study on Nutritional Values and Bio-Analytical Variance. LWT - Food Science and Technology, 31(2), 150-154. https://doi.org/10.1006/fstl.1997.0324

Mailu, S. K., Muhammad, L., Wanyoike, M. M., \& Mwanza, R. N. (2012). Rabbit meat consumption in Kenya (p. 11). MPRA Paper No. 41517.

McEachern, M. G., \& Schröder, M. J. A. (2004). Integrating the voice of the consumer within the value chain: a focus on value- based labelling communications in the fresh-meat sector. J Consum Mark, 21(7), 497-509. https://doi. org/10.1108/07363760410568716.

McLean-Meyinsse, P. E. (2000). Assessing the Market Outlook for Rabbit Meat in Louisiana and Texas. Journal of Food Distribution Research, 31(1), 139-144.

Montero-Vicente, L., Escribá-Pérez, C., Baviera-Puig, A., \& Buitrago-Vera, J. (2018). Analysis of the commercial value of rabbit meat based on positioning of the different types of fresh meat. Spanish Journal of Agricultural Research, 16(3), e0110. https://doi.org/10.5424/sjar/2018163-13407

Mottin, C., Eiras, C. E., Chefer, D. M., da Cunha Barcelos, V., Ramos, T. R., \& do Prado, I. N. (2019). Influencing factors of consumer willingness to buy cattle meat: An analysis of survey data from three Brazilian cities. Acta Scientiarum. Animal Sciences, 41, 43871. https://doi.org/10.4025/actascianimsci.v41i1.43871

Nakyinsige, K., Sazili, A. Q., Aghwana, Z. A., Zulkifli, I., Gohc Abu Bakar, Y. M. F., \& Saraha, S. A. (2015). Development of microbial spoilage and lipid and protein oxidation in rabbit meat. Meat Science, 108, 125131. https://doi.org/10.1016/j.meatsci.2015.05.029

Petrescu, D. C., \& Petrescu-Mag, R. M. (2018). Consumer behaviour related to rabbit meat as functional food. 
World Rabbit Sci., 26, 321-333. https://doi.org/10.4995/wrs.2018.10435

Szendrö, K. (2016). Consumer Perceptions, Concerns, and Purchasing Practices of Rabbit Meat in Hungary. Journal of Food Products Marketing, 22(6), 683-693. http://dx.doi.org/10.1080/10454446.2015.1121437

Udomkun, P., Ilukor, J., Mockshell, J., Mujawamariya, G., Okafor, C., Bullock, R., ... Vanlauwe, B. (2018). What are the key factors influencing consumers' preference and willingness to pay for meat products in Eastern DRC? Food Sci Nutr., 6, 2321-2336. https://doi.org/10.1002/fsn3.813

Uys, P., \& Bisschoff, C. (2016). Identifying consumer buying preferences of beef. Problems and Perspectives in Management, 14(4), 256-263. https://doi.org/10.21511/ppm.14(4-1).2016.15

Zotte, A. D. (2002). Perception of rabbit meat quality and major factors influencing the rabbit carcass and meat quality. Livestock Production Science, 75, 11-32. https://doi.org/10.1016/S0301-6226(01)00308-6

Zotte, A. D., \& Szendrő, Z. (2011). The role of rabbit meat as functional food. Meat Science, 88, 319-331. https://doi.org/10.1016/j.meatsci.2011.02.017

\section{Copyrights}

Copyright for this article is retained by the author, with first publication rights granted to the journal.

This is an open-access article distributed under the terms and conditions of the Creative Commons Attribution license (http://creativecommons.org/licenses/by/4.0/). 